\title{
Conexões
}

Educação Física, Esporte e Saúde

\section{Fala preta, gestos e palavras da cultura afro-brasileira: o Bumba meu Boi} maranhense

\author{
Raimundo Nonato Assunção Viana ${ }^{1}$
}

\section{RESUMO}

A história do Brasil sempre destinou ao negro um lugar secundário, submetido à escravidão e a trabalhos menos valorizados no contexto cultural. Todavia, os povos indígenas e negros sempre foram importantes na formação da nação brasileira. Desse modo, o objetivo desse texto foi trazer à superfície a demonstração da cultura afro-brasileira a partir de uma de suas manifestações: o bumba meu boi. Essa manifestação demonstra a construção da estética presente na cultura apesar do desenraizamento gerado pelos brancos.

Palavras-Chave: Cultura afro-brasileira. Estética. Gestos.

\footnotetext{
${ }^{1}$ Universidade Federal do Maranhão

Recebido em: 8 maio 2018

Aprovado em: 30 jun. 2018

Contato: raimundo.viana@terra.com.br
} 


\section{Black speach; gestures and words of afro- brazilian culture: the maranhense's Bumba meu Boi}

\section{AbStract}

The history of Brazil has always assigned to the Negro a secondary place, subjected to slavery and works less valued in the cultural context. However, indigenous and black peoples have always been important in shaping the Brazilian nation. Thus, the purpose of this text is to bring to the surface the demonstration of Afro-Brazilian culture from one of its manifestations: the bumba meu boi. This manifestation demonstrates the construction of the esthetics present in the culture despite the uprooting generated by the whites.

Keywords: African-brazilian culture. Aesthetics. Gestures.

\section{Habla negra; de la cultura afro-brasileña: el Bumba meu Buey maranhense}

\section{RESUMEN}

La historia de Brasil siempre ha destinado al negro un lugar secundario, sometido a la esclavitud ya trabajos menos valorados en el contexto cultural. Sin embargo, los pueblos indígenas y negros siempre fueron importantes en la formación de la nación brasileña. De este modo, el objetivo de este texto es traer a la superficie la demostración de la cultura afro-brasileña a partir de una de sus manifestaciones: el bumba mi buey. Esta manifestación demuestra la construcción de la estética presente en la cultura a pesar del desarraigo generado por los blancos.

Palabras Clave: Cultura afro-brasileña. Estética. Gestos. 


\section{INTRODUÇÃO}

A história oficial do Brasil destinou ao negro um espaço que começa e termina na escravidão. Sobre a civilização negro-africana espalhou-se uma nuvem de esquecimento e exotismo, que o senso comum reproduz em suas narrativas que situam as culturas africanas e indígenas como primitivas. A história do Brasil vem sendo contada, como é comum nas sociedades ocidentais, na perspectiva dos grupos sociais hegemônicos, ou seja, daqueles que detêm o poder político, geralmente conquistado pela força das armas e não pela sofisticação das ideias. Por isso, o lugar do índio e do negro, embora sejam essenciais na formação social brasileira, parece não ter sido encontrado para a historiografia oficial, que optou pelo olhar eurocêntrico sobre as nossas matrizes civilizatórias (SANTOS, 2006).

A palavra "desenraizamento" neste texto, incorpora o sentido de trazer à superfície, fazer aparecer a importância e sustentabilidade da cultura africana na formação da sociedade brasileira. Importância esta, negligenciada por muito tempo pela historiografia brasileira apontada como oficial, e pelo pensamento também colocado como hegemônico. Portanto, "desenraizar" toma o mesmo sentido que Santos (2006) emprega quanto ao conhecimento da história do Negro no Brasil:

é reconhecer a necessidade de que ela seja contada enxergando-o como sujeito e, portanto, igual. Para tanto, devemos nos convidar a uma empreitada nova, no sentido de abrir os nossos velhos livros de história e relê-lo, buscando compreender os significados de suas capas e títulos que, na maioria das vezes, apresentam homens e mulheres em situação de trabalho escravo. Abolida a escravidão, a imagem negra simplesmente some dos manuais de história e se fixa de forma perversa no imaginário (SANTOS, 2006, p. 148).

É aprender sua história, memória, práticas culturais, seu pensamento, sua estética, sua produção e transmissão de conhecimento. Nesse sentido buscamos reencontrar na estrutura do Bumba-meu-boi maranhense unidades de significados para chegarmos aos dados originários de história, de memória, de prática cultural do segmento negro e sua importância na cultura brasileira, em especial os aspectos relativos à oralidade e os rituais de passagem.

Fala preta constitui-se de coro de vozes de seres humanos remanescentes de povos africanos que aqui se estabeleceram a partir do processo de escravidão e que perduram com suas danças, gestos, rituais, costumes e línguas. A palavra, verbo portador do germe da criação é colocado no despontar desta ultima, como a primeira manifestação divina antes que qualquer coisa tenha tomado forma. No pensamento, grego, a palavra logos significou não só a palavra, a frase, o discurso, mais também a razão e inteligência, a ideia e os sentidos profundo de um ser. O próprio pensamento divino (CHEVALIER; GHEERBRANT, 1982). 
A palavra, o diálogo, o argumento, o conselho constituem práticas essenciais na vida do dia a dia da comunidade entre os povos africanos. No continente africano o homem é um ser de palavra, é um ser que fala e sua voz tem o valor de uma referência forte. Por isso há uma recusa a toda palavra que não respeita a dignidade do ser humano, isto é, há uma afirmação do Ser Humano pela sua própria palavra. Nesse sentido para a o povo africano "A palavra é divinamente exata e deve ser exato com ela. A língua que falseia a palavra vicia o sangue daquele que não diz a verdade. Quem estraga a sua palavra, estraga a si mesmo" (CONCEIÇÃO; SIQUEIRA, 2001, p. 25).

A palavra, instrumento de comunicação privilegiado entre os africanos escravizados ou não, é ao mesmo tempo, sopro divino de humanidade, far-se-á presente com seu som e sentidos históricos, mostrando que o retrato do saber, não é o saber e que a história contada pode ser outra, se o seu sujeito for o narrador (SANTOS, 2006).

É próprio do gesto humano significar para além de sua simples existência. De fato, inaugurar sentidos. Cada um deles é um começo, comporta uma sequência ou recomeço na medida em que não é como acontecimento opaco, e fechado em si mesmo e acabado de uma vez por toda, ele é de antemão aliado ou cúmplice de todas as outras tentativas de expressão.

Os gestos fazem existir a cultura e estão entre si numa afinidade de principio que faz deles não só os momentos de única tarefa, mas também, um exige do outro em sua diferença. Neste sentido que lançamos mão de palavras e gestos do bumba-meu-boi maranhense para aludir ao desenraizamento na cultura afro-brasileira.

\section{África, Ventre Fértil do Mundo}

Santos (2006) afirma que a presença negra no Brasil vem sendo mostrada desde os primeiros anos da colonização portuguesa, e que o ano de 1532 é indicado por vários historiadores como marco de entrada dos primeiros negros que aqui chegaram na condição escravos, por ressalta que a história do negro começa muito antes no continente africano, onde uma civilização, organizada através da palavra falada, vem construindo dentro de uma rica diversidade cultural, a sua história. Essa afirmativa encontra corroboração na seguinte inferência:

As últimas descobertas científicas reconhecem a África em seu lugar de berço da humanidade e atestam que os Africanos são originários do seu próprio continente. É possível mapear o caminho do povo de origem africana desde a pré história aos nossos dias, partindo da região dos grandes lagos atravessando a bacia do Nilo, criando as civilizações Sudanesa, Nilótica e Egípcia [...]. Os egípcios pertencem a um grupo étnico africano que vem da Etiópia através do Rio Nilo. [...] O totemismo, a circuncisão, a concepção de realeza, a cosmogonia, os distintos níveis e formatos de organização social africana e suas complexidades, a idéia de sociedades matriarcais, os sistemas de parentesco, a complexidade lingüística, a escrita, a gramática, o uso de 
vocabulário integrado de palavras e sinais com múltiplos significados, além de todos os avanços científicos, artísticos que marcavam as civilizações egípcias demonstram a tese de que através das suas origens identificadas no Egito, África é o Ventre Fértil do Mundo (CONCEIÇÃO; SIQUEIRA, 2001, p. 12).

E também:

É no sentido desta reflexão que se inscrevem entre as sociedades e culturas africanas as grandezas das civilizações tradicionais presentes no Continente Africano: As pirâmides do Egito; Os Templos do Zimbawe; A força do ferro em Gana; Forja das esculturas em bronze no Benin; Tecelagem em Algodão; Arquitetura que cria formas redondas para construção das casas; Os cultivos das plantas que são descobertas pela medicina; As formas tradicionais de fazer justiça, que estabelecem as regras do direito; A Arte de reunir as palavras, que cria contos, cantos, lendas, histórias, provérbios; A tradição oral que se organiza e cria legitimidade, enquanto voz e tradição dos ancestrais, em diferentes espaços e tempos do Continente Africano CONCEIÇÃO; SIQUEIRA, 2001, p. 12).

Assim, a África enquanto ventre fértil, jorra vida conhecimento, espiritualidade, ritmo, música, para o mundo inteiro, a sua lição na construção de seres humanos transmissores de cultura, formadores de jovens, guardiães de costumes, mantenedores e recriadores de crenças, lendas, cantos, contos, provérbios, versos, que encerram sentidos sociais, culturais, religiosos, éticos, constituintes da cultura da sociedade a qual pertencem, se repetem, se renovam nas diferentes civilizações e difundem-se no mundo inteiro e são chamadas afro-brasileiras, afroeuropeias, afro-asiáticas. É a marca do ser africano que se espalhou pelo mundo inteiro. Afro é, portanto, todo ser humano, toda cultura, toda sociedade que tem origem no continente africano, mesmo desenvolvendo-se em espaços e tempo diferentes (CONCEIÇÃO; SIQUEIRA, 2001).

\section{A Participação Africana na Formação Cultural Brasileira}

Ratt e Damascena (2006) em seus estudos sobre a participação africana na formação cultural brasileira comentam que os africanos, na sua maioria, ao serem forçados a vir para o Brasil, traziam consigo sua própria África:

[...] composta de lembranças e desejos. Um patrimônio cultural, material e imaterial inscrito nos objetos, hábitos, textos orais escritos, rituais, jogos, folguedos e muitas histórias. Lembranças e saberes que dizem respeito à religião, à tecnologia e ao trabalho, que podem ser preservados quando recriados nos estilos de vida, nas habilidades artísticas, nos rituais religiosos 
e nas soluções técnicas e procedimentos intelectuais (RATT; DAMASCENA, 2006, p. 170).

Os autores argumentam que no Brasil, com o contínuo movimento do tráfico negreiro, ocorria uma regular chegada de africanos aos portos, o que contribuía para realimentar as lembranças, os traços, os valores e os costumes, que, pela distância, tenderiam desaparecer das práticas em terras tão longínquas. Ressaltando que, não se pode perder de vista que a travessia e a transposição dos grupos para cá foi bastante violenta, causando mudanças bruscas para essa população.

A dinâmica da exploração dos negros africanos em solo brasileiro conduziu a novas formas de entender a realidade, tomada pelos de quem traz as suas tradições para poder dialogar com o presente. Diferentes origens possivelmente produziram diferentes formas de encarar a realidade, formando um verdadeiro mosaico, no qual se demonstra a diversidade cultural e social, pois havia muitas formas de ser escravizado, pois:

As formas de escravidão diferenciavam-se, algumas vezes, alguns vezes, pela nação de origem ou, sobretudo, pela atividade que o indivíduo desempenha ou ainda se estava na cidade ou no campo [...]. Os africanos trazidos compulsoriamente paro Brasil, tiveram de lidar com o desconhecido e o arbitrário. Foi nesse contexto, numa situação concreta e desfavorável, que essa população teve de se reinventar, recorrendo a negociações que se constituíam cotidianamente ou, ainda muitas vezes, em formas de resistência (RATT; DAMASCENA, 2006, p. 170).

Ratt e Damascena (2006) inferem que para melhor compreender a participação do segmento negro na formação do povo brasileiro, três dimensões são de fundamental importância: a história, a memória, as práticas culturais. Segundo os autores, a memória, ao lado da identificação com certos valores culturais, aponta fortes sinais dos elementos que compõem a participação da população negra na cultura brasileira, com toda a multiplicidade que ela carrega, reafirmam sua reflexão em Benjamim (s,d) "Um acontecimento vivido é finito ou, pelo menos, encerrado na esfera do vivido. Ao passo que o acontecimento lembrado é sem limites, porque é apenas uma chave para tudo o que veio antes e depois (BENJAMIM, s/d, p. 27 apud RATT; DAMASCENA, 2006).

\section{Palavras E Gestos do Bumba Meu Boi MARANHENSE}

Segundo estudos de Azevedo Neto (1983), o Bumba-meu-Boi maranhense divide-se em Grupos, influência maior ou menor das etnias negra, branca e indígena, na batida básica da bateria, ideia central, guarda-roupa, e no bailado. Os subgrupos são derivados de 
alterações desses grupos devido à região de origem. A divisão em "sotaques" ou "estilos" decorre da predominância de determinado instrumento musical. Os sotaques são: Zabumba, Orquestra, Matraca, Pandeirões e Costas de Mão.

O Bumba-meu-boi teria nascido de negros escravos, mamelucos, mestiços, gente pobre, agregados de engenhos e fazendas, trabalhadores da roça e pequenos ofícios das cidades interioranas, por volta das últimas décadas do século XVIII. Teria começado na forma inicial, boi de canastra, semelhante à manifestação que ocorria em Portugal e Espanha, consistindo em armação em vime, coberta de pano pintado, cabeçorra bovina, ampla cornadura, unicamente usado para dispersar e afugentar os curiosos de uma função apresentada ao ar livre (CASCUDO,1980).

Essas manifestações em torno do boi em Portugal e Espanha, as quais se refere Cascudo (1980), tratam-se das "Tourinhas" imitação de uma corrida de touros, utilizando novilhas mansas ou sendo estes representados por canastras cobertas com tecidos, era composta com cabeças falsas de touro e assentadas sobre duas rodas e eram movidas por um homem do lado de dentro. As "tourinhas" eram utilizadas para o exercício dos praticantes do toureio (Silva, 1958). A canastra consistia em uma cesta larga e pouco alta entretecida de verga, espécie de vara flexível e delgada (FIGUEIREDO, 1922).

Ramos (1971) afirma a contribuição decisiva do Negro africano na formação do Bumba-meu-boi, que, ao chegarem ao Brasil, teriam adaptado suas próprias instituições aos velhos autos populares trazidos pelo colonizador português e às manifestações de procedências ameríndias. O autor considera o Bumba-meu-boi como sobrevivência totêmica, atendo-se a informação que algumas das tribos importadas para o Brasil, no tráfico de escravos pertenciam a povos totêmicos, a exemplo dos povos bantos e sudaneses, ainda que, ressalva o autor, muito embora, entre muitas tribos do Sudão não se possa falar propriamente em verdadeiro totemismo, tratando-se apenas de afinidades entre certos animais e plantas e os membros da clã.

A afirmação de Ramos (1971) é contestada por Vieira Filho (1977), ao comentar que não se encontra nem as ligações totêmicas sinalizadas pelo autor, nem remotas ligações zooculturais da Índia e do Egito, que alguns autores discutem sobre o folguedo. Para Vieira Filho (1977), no que concerne ao Bumba-meu-boi, este está ligado ao ciclo econômico do pastoreio, no começo da vida colonial brasileira.

$\mathrm{O}$ auto ou trama que constitui o enredo da festa é comum a todas as áreas brasileiras onde ocorre o folguedo. Versa sobre a história de Pai Francisco e Mãe Catirina, trazendo elementos satíricos que remetem às questões raciais e sociais. Pai Chico (um negro), rouba um boi do patrão (elemento branco), para lhe retirar a língua e dar a Catirina que estava grávida e desejosa de comer língua de boi. Ao recapturar o animal, o patrão procura salvá-lo com a intervenção dos pajés e cazumbás (elemento ameríndio). Para contentamento geral, o 
boi ressuscita e os brincantes entoam cânticos de louvor e dançam ao seu redor que ao seu turno faz evoluções diversas (VIEIRA FILHO, 1977).

Marques (1999) afirma que, como auto popular, o Bumba-meu-boi nasce no final do século XVII em meio às lutas sociais, agitado pelos grandes combates entre senhores, escravos, índios e brancos no seio da sociedade patriarcal e escravista de um Brasil colonial, pressionado pelas revoltas populares. Nesse sentido, a autora infere que:

Em meio a essa realidade, o Bumba-meu-boi torna-se uma sátira ao patriarcalismo escravista: do fazendeiro que massacra os negros e índios, mas baixa a cabeça para a nobreza; do doutor burguês, estudante de Coimbra, metido a entender de tudo, mas que no fim só consegue resolver o problema com ajuda do curandeiro; do delegado autoritário, valente com a tropa e covarde sem ela, e do sacerdote, sempre pronto a atender às elites com base num discurso populista. Todos caricaturados em personagens, em que a inversão de papéis e de discursos violentos torna-se um ajuste de contas (MARQUES, 1999, p. 57).

O registro mais antigo sobre o Bumba-meu-boi no Brasil foi veiculado em 1840 em "O Carapuceiro" - jornal publicado em Recife pelo Padre Miguel do Sacramento Lopes Corrêa, onde já descrevia o enredo, os personagens e o bailado. E é Cascudo que segue descrevendo cenas e cenários

De quanto recreios, folganças e desenfados populares há neste nosso Pernambuco, eu não conheço um tão tolo, tão estúpido e destituído de graça como o aliás bem conhecido Bumba-meu-boi. Em tal brinco não se encontra um enredo nem verossimilhança, nem ligação: é um agregado de disparates... Um negro metido debaixo de uma baieta é o boi, um capadócio, enfiado pelo fundo de um panacu velho chama-se cavalo - marinho; outro, alapardado, sob lençóis, denomina-se burrinha; um menino com duas saias, uma da cintura para baixo, outra da cintura para cima, terminando para a cabeça como uma urupema, é o que se chama caipora: além disso há outro capadócio que se chama Mateus. O sujeito do cavalo marinho é o senhor do boi, de burrinha, da caipora e do Mateus...Todo o divertimento cifra-se em o dono de toda esta sucia fazer dançar ao som de violas, pandeiros e de uma infernal berraria o tal bêbado Mateus, a burrinha, a caipora e o boi que com efeito é animal muito ligeirinho, trêfego e bailarino (CASCUDO, 1980, p. $34)$.

Notadamente, em relação ao surgimento do Bumba-meu-boi no Maranhão, Vieira Filho (1977) confirma as notas de Cascudo, concordando que nesse Estado, a brincadeira teria surgido provavelmente por volta dos últimos anos do século XVIII como brincadeiras de escravos nas fazendas de engenhos e comenta também que, na capital, a polícia sempre andava às voltas com esses folguedos por julgá-los prejudiciais à ordem pública, chegando a proibir sua exibição nas décadas de 50 e 60 do século XIX. O autor faz referência a essa proibição, relatando que em 1858 o jornal “O Globo", editado em São Luís, estampava notícia 
tachando o Bumba-meu-boi de brincadeira indecente, grotesca, bárbara e que por isso devia ser proibida.

Azevedo Neto (1983) distribui os Bumba-meu-boi do Maranhão da seguinte maneira: Grupo Africano ${ }^{1}$, Subgrupo de Zabumba ou Zona de Guimarães (sotaque de Leonardo, sotaque de Antero, sotaque de Canuto, sotaque de Laurentino, sotaque de Newton, Sotaque de Lauro), Subgrupo da zona do Itapecuru (sotaques de Coroatá, sotaque de Caxias, sotaque de Codó e sotaque de Itapecuru), Subgrupo de Cururupu, subgrupo do Mearim (sotaques de Pedreiras, sotaque de Bacabal). Grupo Indígena, Subgrupo de Penalva, Subgrupo da Ilha, Bois da Ilha ou de Matraca (sotaques da Madre Deus, sotaque de Iguaíba, sotaque de São José de Ribamar, sotaque de Maracanã, sotaque de Matinha, sotaque da Maioba), Subgrupo da Baixada, Bois da Baixada (sotaque de Pindaré, sotaque de Viana, sotaque de São João Batista. Grupo Branco, Subgrupo de Orquestra, Bois de orquestra (sotaque de Rosário, sotaque de Axixá).

O Grupo Africano é provavelmente o mais amplo e mais antigo representante do Bumba-meu-boi maranhense; suas raízes são originalmente africanas e seus subgrupos se expandiram por todo o Estado; nos demais grupos, os subgrupos aconteceram próximos uns dos outros. A citação que segue explica o fato de o Grupo Africano ter tamanha dimensão.

O fato é que enquanto o índio brasileiro era empurrado no sentido de determinadas regiões pra um confinamento forçado ou espontâneo; enquanto o branco permanecia próximo às áreas mais povoadas, o negro - mandado ou fugido, espalhava-se por todo o Estado, disseminando seus cantos, suas danças seu jeito de divertir-se (AZEVEDO NETO, 1983, p. 24).

O grupo Africano tem como ponto forte o bailado sustentado pelas batidas de tambores. O tambor está presente em quase todas as manifestações e rituais da humanidade, pelo seu caráter mágico, aproximando o ser humano dos ritmos da natureza, assim como, permitindolhe o êxtase e o transe, o desligamento terreno, material e aproximando-o do plano espiritual (CHEVALIER; GHEERBRANT, 1982).

O ruído do tambor é associado à emissão do som primordial, origem da manifestação e, mais geralmente, ao ritmo do Universo. Na China antiga está associado à trajetória aparente do sol e da água, elemento do norte hibernal. Na Índia é utilizado como tambor de guerra, relacionado ao trovão e ao raio sob seu aspecto destruidor. O tambor também é utilizado como arma psicológica, desfazendo internamente toda a resistência do inimigo; como força sagrada, trovejando como o raio, ou como caráter mágico tal qual os utiliza os Xamãs das regiões altaicas (CHEVALIER; GHEERBRANT, 1982).

\footnotetext{
${ }^{1}$ Sobre esse Grupo é que discorreremos mais, considerando o recorte do texto. Maiores informações sobre os demais, ver Azevedo Neto, Américo. Bumba-Meu-Boi no Maranhão (1983). 
$\mathrm{Na}$ África, o tambor apela à descida dos favores celestes. Está associado a todos os acontecimentos da vida humana, é o eco sonoro da existência:

Instrumento africano por excelência, dizem os especialistas do Continente Negro, o tambor é, no sentido pleno da palavra o logos da nossa cultura, identificando-se com a condição humana, de que é a expressão, ao mesmo tempo rei, artesão, guerreiro, caçador, rapaz na idade da iniciação, a sua voz múltipla traz em si a voz do homem, com o ritmo vital da sua alma com todas as voltas de seu destino. Ele identifica-se com a condição da mulher, e acompanha a marcha do seu destino. Assim também não é de admirar ver-se em certas funções especiais, o tambor nascer com o homem, para morrer com ele (CHEVALLIER; GHEERBRANT, 1982, p. 630).

\section{A Tradição Oral-Oralidade Africana E O Bumba Meu Boi Maranhense}

A maioria dos povos africanos vive em vilas, povoados, comunidades, muitos deles em seus próprios lugares de origem. A colonização e escravidão realizaram muitas mesclas, muitas transformações, mas eles recriam, reinventam e mantém parte de suas tradições, principalmente aquelas que não são do eixo familiar tradicional. São nestes locais onde eles cultivam suas tradições, falam suas línguas, conhecem as tradições de seus vizinhos, preparam novas gerações para manter a continuidade das heranças dos seus antepassados. Os profissionais da tradição mais reconhecidos na África tradicional e contemporâneo são os Griots e os Domas (CONCEIÇÃO; SIQUEIRA, 2001).

O Griot é um nome de origem Bambará, para personagens africanos denominados contadores de histórias, que eles sabem de memória e acumulam, reunindo séculos e mais séculos de crenças, costumes, lendas, contos, lições de sabedoria [...]. O Doma é a categoria mais nobre de contadores de história, aquele que tem o papel de criar harmonia, de colocar ordem em volta do ambiente, da audiência nas reuniões da comunidade [...]. Os contadores de histórias, são ao mesmo tempo poetas e músicos. Eles conhecem muitas regiões, conhecem muitas terras, conhecem muita gente e suas histórias. Eles se preparam viajando de comunidades em comunidades escutando os contos, as vidas, as experiências de famílias inteiras que formam as linhagens, as culturas de uma dada sociedade (CONCEIÇÃO; SIQUEIRA, 2001, p. 25).

Os modos de difusão oral ainda conservam um status privilegiado no universo do Bumba-meu boi. Como verdadeiros Griots ou Domas, os amos, os donos das brincadeiras constituem-se como guardiões da tradição. A oralidade na transmissão dos conhecimentos tem forte representatividade na composição das toadas. Assim nos ensaios, encontramos esse dado originário quando o amo inicia tocando uma toada nova, ainda que tropegadamente é 
acompanhada pelos demais. A repetição das estrofes chegar à batida ideal para a toada. As interrupções são frequentes e todos opinam pela melhor entonação, correção da melodia, supressão e acréscimo de palavras, frases, mudanças do lugar de palavras e de frases. É uma construção coletiva com base na percepção e na memória. A composição e a conservação dessas toadas ainda comportam grande índice de oralidade, termo utilizado por Zumthor (1993) para designar tudo o que, no interior de um texto, informa sobre a intervenção da voz humana em sua publicação, na mutação que o texto passou, uma ou mais vezes, de um estado virtual à atualidade e existiu na memória de certo número de indivíduos. Podemos dizer que as toadas no Bumba-meu-boi não apenas embalam o bailado de seus brincantes, mas como verdadeiras poesias, têm a função da voz poética descrita por Zumthor (1993):

A voz poética assume a função coesiva e estabilizante sem a qual o grupo social não poderia sobreviver. Paradoxo: graças ao vagar de seus intérpretes - no espaço e no tempo, na consciência de si -, a voz poética está presente em toda parte, conhecida de cada um, integrada nos discursos comuns, e é para eles a referência permanente e segura. Ela lhes confere figuradamente alguma extratemporalidade: através dela, permanecem e se justificam. Oferece-lhes o espelho mágico do qual a imagem não se apaga, mesmo que eles tenham passado (ZUMTHOR, 1993, p.139).

As palavras são gestos e nas suas construções sob forma de frases, poesias contos, prosas e toadas, o ser humano inspeciona o mundo, permanecem e justificam sua presença. Pelo canto, pela sua toada o brincante firma-se no espaço e no tempo. A memória não é só receptáculo de lembranças do passado, mas processo por onde possa reconhecer seu estado presente e projetar futuros é: “[...] palavra viva, da qual emana a coerência de uma inscrição do homem e sua história, pessoal e coletiva, na realidade do destino" (ZUMTHOR, 1993, p. 140).

As toadas dos grupos de Bois de zabumba que tinham como característica marcante serem longas e faladas, em algumas composições apresentam uma construção com estrofes mais curtas. Todos os anos são compostas novas toadas, ainda que a partir da década de oitenta do século XX, tenha havido um movimento de registro e documentação das mesmas, num primeiro momento com os discos de vinil e hoje com os CD's e DVD's, principalmente os grupos mais antigos não costumam repeti-las de um ano para outro, salvo solicitação do público ou de quem contrata a brincadeira. 


\section{Celebrações Rituais Africanas: Vestígios No Bumba MeU Boi MARANHENSE}

As celebrações rituais na África acompanham o ciclo da vida; Iniciações desde o nascimento; Apresentação à família e à sociedade no processo de maturidade; Ritos de dedicação da vida sob a proteção dos ancestrais; Ritos de passagem que preparam as crianças e os jovens, homens, homens e mulheres para a vida adulta; Nestes rituais eles aprendem tudo que se relaciona com a vida cotidiana, com a vida em sociedade e com crenças religiosas; Há pessoas preparadas para exercerem as funções de mestres destas escolas de iniciação e desses rituais de passagem; Os grupos são organizados segundo classes de idade, separando grupos de meninos e grupos de meninas dos mesmos grupos étnicos, da mesma cultura (CONCEIÇÃO; SIQUEIRA, 2001)

As celebrações rituais no bumba meu boi, se materializam no ritual de Batismo e de morte. Vejamos inicialmente sobre o Batismo.

Etimologicamente, a palavra batismo significa banho. Foi o nome dado às atividades de João Batista no deserto, segundo o evangelista Mateus, de acordo com o Novo Testamento da Bíblia Sagrada (MT 3, 13-17, 1988).

A imersão ou aspersão por uma água virgem é encontrada nas tradições de numerosos povos, associados aos ritos de passagem e, principalmente, ao nascimento e à morte. É um símbolo de purificação e de renovação em muitas religiões.

Purificar significa restituir o sentimento das manchas provenientes das faltas e dos contatos terrestres, aspirando a uma vida superior, celeste, regressando às fontes da vida. A purificação está ligada à água, ao fogo e ao sangue, o contrário deste, ou seja, o impuro encontra-se apegado à terra, às coisas terrestres (CHEVALIER; GHEERBRANT, 1982).

Símbolo de purificação e de renovação, o rito de imersão está presente em diversas religiões entre as quais o Judaísmo, associado ao rito de passagem do nascimento e da morte, diferenciando, portanto, daquilo que conhecemos na tradição cristã do rito de imersão, do batismo de João Batista. Este não visa uma purificação ritual, mas moral, adquirindo um caráter de iniciação com valor escatológico, introduzindo no grupo o qual está submetido a espera do Messias, constituindo por antecipação sua comunidade (CHEVALIER; GHEERBRANT, 1982).

Os autores enfatizam que: 
Quaisquer que sejam as modificações trazidas pela liturgia das diversas confissões cristãs, os ritos do batismo continuam a incluir dois gestos ou duas fases de notável alcance simbólico: a imersão e a emersão. A imersão, hoje reduzida à aspersão, é por si só rica de muitas significações: indica o desaparecimento do ser pecador nas águas da morte, a purificação através da água lustral, o retorno do ser às fontes de origem da vida. A emersão revela a aparição do ser em estado de graça, purificado reconciliado como uma fonte divina de vida (CHEVALIER; GHEERBRANT, 1982, p. 114).

Em relação a imersão e a emersão, Elíade (1996) comenta que as águas simbolizam a soma universal das virtualidades, reservatório de todas possibilidades de existência, precedendo todas as formas e sustentando toda criação.

[...] a imersão na água simboliza a regressão ao pré formal, a reintegração no modo indiferenciado da pré-existência. A emersão repete o gesto cosmogônico da manifestação formal; a imersão equivale a uma dissolução das formas. É por isso que o simbolismo das Águas implica tanto a Morte como o Renascimento. $O$ contato com a água supõe sempre uma regeneração: de um lado, porque a dissolução é seguida de um "novo nascimento", de outro, porque a imersão fertiliza e multiplica o potencial da vida (ELÍADE, 1996, p. 152).

Elíade (1996) afirma que em qualquer grupo religioso que se encontrem, as águas conservam suas funções, desintegrando e eliminando as formas, lavando o pecado, ao mesmo tempo purificando e regenerando "[...] seu destino é o de preceder à Criação e de reabsorvê-la, incapazes que são de ultrapassar sua própria modalidade, ou seja, de manifestar-se em forma" (ELÍADE, 1996, p.152).

Particularmente ao simbolismo aquático na Tradição Cristã, Elíade (1996) relata:

$\mathrm{Na}$ formação do homem em si, Deus utilizará a água para acabar a sua obra [...]. Toda água natural adquire logo pela antiga prerrogativa com a qual ela foi honrada na sua origem, a virtude da santificação no sacramento quando Deus é invocado para tanto. Assim que as palavras são pronunciadas, o Espírito Santo, que desceu dos céus, pára sobre as águas santificando-as por sua fecundidade; as águas, assim santificadas, impregnam-se por sua vez de virtude santificante... o que curava antes o corpo cura hoje a alma; o que procurava a saúde no tempo procura a salvação na eternidade (ELÍADE, 1996, p. 153).

Os ritos católicos do batismo traduzem a dupla intenção de purificar e de vivificar. Em um primeiro plano, o batismo lava o homem de sua sujidade moral, outorgando-lhe a vida sobrenatural, ou seja, passagem da morte à vida; em outro plano, evoca a morte e a ressurreição de Jesus Cristo. O batizado assimila-se ao salvador; sua imersão na água simboliza a colocação no túmulo e sua saída a ressurreição; e em um terceiro plano, liberta a alma do batizado da sujeição ao demônio. Portanto, toda essa liturgia realiza na alma do 
batizado, o nascimento da graça, princípio interior de aperfeiçoamento espiritual (CHEVALIER; GHEERBRANT, 1982). Os autores destacam o rico simbolismo de gestos e objetos que intervém na administração, como: imposição das mãos, sinal da cruz, tradição do sal da sabedoria, abertura da boca e das orelhas, renúncia ao demônio, recitação do credo, unção de diversos óleos de exorcismo e eucaristia.

O batismo é um rito de transformação de status e, como todo ritual de transformação, seu objetivo central é a reestruturação radical da identidade do participante, compreendido assim como rito de passagem, como ritual de transformação que confere aos batizandos um status novo, um status livre de qualquer obrigação com a velha ordem.

O simbolismo do batismo da Igreja Católica é transferido aos grupos de Bumba-meuboi. Através do batismo, vivifica-se, purifica-se, renova-se esse ente, dando-lhe status de cristão sob a proteção divina. Outorga-lhe ao seu objeto de adoração, o boi, a vida sobrenatural, a sua passagem de morte para vida.

Em seus estudos, ao comentar sobre o ritual de batismo no Bumba-meu-boi, Marques (1999) ressalta que:

o que o batismo propõe ao Bumba-meu-boi é uma afirmação de identidade específica: o amadurecimento de um ser que nasceu pagão, sob auspício de São João, para ser mostrado ao mundo como cristão sem manchas ou culpas de qualquer natureza [...]. Após o batismo, o Bumba-meu-boi não é um ente, mas o ente, aquele que vai representar o mundo vivido da comunidade num outro espaço, agora público, levando as mensagens e tornando-as conhecidas, acessíveis a todos para trazer de volta o feed-back necessário à continuação tanto do ente como da própria comunidade (MARQUES, 1999, p. 140).

Assim como o batismo, o ritual de morte no Bumba meu boi constitui dado originário de tradições africanas na cultura brasileira.

Em relação ao ritual de morte inferimos que, a morte designa o fim absoluto de qualquer coisa de positivo: um ser humano, um animal, uma planta, uma amizade, uma aliança, a paz, uma época. Simbolicamente, a morte é o aspecto perecível e destrutível da existência, indica aquilo que desaparece na evolução irreversível das coisas, mas também a introdutora aos mundos desconhecidos dos infernos e paraísos. É revelação e introdução; todas as introduções atravessam uma fase de morte, antes de abrir acesso a uma vida nova. A exemplo, o batismo. A morte tem um sentido psicológico, liberta das forças negativas e regressivas, desmaterializa e libera as forças de ascensão do espírito. A morte e a vida coexistem. Com inúmeras significações, não sendo um fim em si mesmo, abre o acesso ao reino do espírito, à vida verdadeira (CHEVALIER; GHEERBRANT, 1992): 
No sentido esotérico, ela simboliza a mudança profunda porque o homem passa sob o efeito da iniciação. "O profano deve morrer para que renasça a vida superior conferida pela iniciação". Se não morre para o seu estado de imperfeição, impede para si próprio qualquer progresso iniciático (CHEVALIER; GHEERBRANT, 1982, p. 461).

A morte é um dado humano, antropológico, uma espécie de vida que prolonga de uma forma ou de outra a vida individual. O cuidado com os seus mortos, ritos a que são submetidos, a crença numa passagem, em uma pós-vida revelam a crença na imortalidade (MORIN, 1976).

Esta imortalidade pressupõe, contudo, não a ignorância da morte, mas, pelo contrário, o reconhecimento da sua chegada. Pois se a morte, como estado, está assimilada à vida, pois que repleta de metáfora de vida, ela é, quando sobrevém, tomada precisamente como mudança de estado, "qualquer coisa" que modifica a ordem normal da vida (MORIN, 1976, p. 26).

A morte é reconhecida como lei inelutável, ao mesmo tempo em que se pretende imortal, o homem designa-se a si próprio como mortal "[...] a mesma consciência nega e reconhece a morte, nega-a como aniquilamento, reconhece-a como acontecimento" (MORIN, 1976, p. 26).

Sendo um dado humano, o que podemos observar nos rituais de morte no Bumba-meuboi é a antropomorfização sob o objeto estético "boi”, dando-lhe determinação humana.

O tema "morte" no Bumba-meu-boi está presente tanto no ritual da morte propriamente dito enquanto momento de fechamento de um ciclo de apresentações como também, no auto que dá origem a essa festa, quando Pai Francisco mata o boi preferido da fazenda para tirarlhe a língua e oferecer à sua esposa Mãe Catirina, satisfazendo seu desejo de mulher grávida. Nesse sentido, Braga ([19--]) afirma que a oposição binária em termos de vida e morte está presente no auto: a gravidez, o nascimento, a retaliação do corpo (mata-se o boi e come-se a língua, a oposição entre vida (o velho dá luz ao novo) e a ressurreição, como também como eixo estrutural entre a narrativa mítica da Ilha de Lençóis e a Dança Dramática do Bumbameu-boi.

[...] o touro, resultado da transformação de D. Sebastião precisa morrer a fim de ressurgir o Rei e sua corte. Na crença, mata-se o touro para que viva o Rei, no auto, mata-se o boi para que viva o filho de Mãe Catirina e Pai Francisco. Em ambos os casos a liquidação do animal por paradoxal que possa parecer significa o triunfo da vida sobre a morte, a redução da incerteza e a posse de novo equilíbrio. É a redenção da vida que só se consegue com o sacrifício votivo (morte) do animal (BRAGA, [19--], p. 59).

A morte assume um caráter ambivalente, não significa fim, mas, renascimento; encontra-se prenhe de vida, em que o velho dá lugar ao novo "[...] o motivo da morte- 
renovação-fertilidade se expressa pela eliminação física e nascimento [...] nesse sistema de imagens, a morte não põe fim a nada de essencial, mas renova o corpo, procriando gerações futuras. O nascimento do novo surge das entranhas da morte que fecunda a vida" (BRAGA, [19--], p. 59).

O ritual de morte nas brincadeiras de Bumba-meu-boi marca oficialmente o fechamento do ciclo de apresentações; acontece entre os meses de agosto e setembro. O ritual da morte também é uma celebração da vida, daquele que pagão, tornou-se cristã e assim aceita a morte como rito de passagem para outra fase e, como celebração, precisa ser festiva. A esse respeito Marques (1999) infere:

Mais do que qualquer outro momento, é na morte que o caráter profano junta-se ao sagrado, numa dialética que celebra os dois pólos contrários primordiais à existência. Todos sabem que é chegada a hora, o destino inevitável de qualquer criatura, mas todos, do mesmo modo, rejeitam a ideia tentando prolongar até o último instante a convivência com o boi, e através dele, com os companheiros de grupo (MARQUES, 1999, p.148).

O sentimento de tristeza pela despedida que o caráter de morte representa, condensa-se com o de festa e alegria nos brincantes por manter viva a saga da brincadeira e acreditar no rito de passagem para uma nova fase.

\section{CONSIDERAÇÕES FINAIS: CULTURA NEGRA, PENSAMENTO E TRANSMISSÃO DE CONHECIMENTOS}

A cultura e as práticas culturais são elaboradas cotidianamente, transformando o conhecimento em experiências de aprendizagem, do mesmo modo que a própria experiência vivida se transforma em conhecimento. Aprende-se por meio da socialização. Em todos os momentos da existência na relação com o outro e nas ações vividas é que nos constituímos. Essa constituição é elaborada constantemente e se revela nas mínimas coisas. Assim por menores normalmente considerados sem importância e triviais, carregam muitos elementos importantes que nos permitem captar a realidade. Considerar os mais diversos elementos presentes nas práticas, como a alimentação, o vestuário, a oralidade, a gestualidade, sonoridade, odores ou sabores, são sinais que permitem decifrar a diversidade e a complexidade da realidade histórica da população afro-brasileira. As expressões culturais e religiosas de matriz africana trazem processo educativos que dizem respeito ao próprio exercícios das apresentações no momento das festas e nos rituais religiosos. Esses processos se revelam na música, na dança, no toque dos instrumentos e nos gestos. São elementos 
impressos no corpo e expressos através da prática e da tradição oral (RATT; DAMASCENA, 2006).

Tambores, sons da natureza, palavras de afagos, palavras de repressão, cantos, continuam impulsionando esse corpo a mover-se no cosmo. Seus gestos, pulsação, contração, respiração, pensamentos são empregados em vencer obstáculos. Corpo desafiado e desafiante para as inúmeras interpretações e compreensões. Deixa-se ler em suas entrelinhas, faz aparecer novas escritas, espera ser lido, compreendido. Daí nosso empreendimento, nossa tentativa de compreender as teses que o corpo africano escreveu, e as que escrevem sobre o mesmo, situando-o no microcosmo do Bumba-meu- boi. Olhar o Bumba meu boi é mergulhar nesse mundo sensível, construído por antepassados africanos e revividos por seus pares no presente. Mundo criado pela conformação de elementos que os rodeiam e que, pelo aguçamento de seus sentidos, criaram maneiras de habitar esse universo, forjaram sistemas de equivalências, técnicas, estilos e fizeram transbordar um microcosmo rico em significações sob as formas de seu bailado, seu batuques, seu canto, seus bordados e como não lhe bastasse a vida terrena, transcenderam-na em seus rituais religiosos, criaram sua hierofonias, vias de comunicação com o céu, com os seus santos, com os seus mitos.

Os corpos brincantes do Bumba meu boi são remanescentes de outros corpos que há muito tempo foram desafiados a calarem-se; primeiro, nos porões dos navios negreiros; em seguida, pela violência policial e elite dominante. Teimam em não calarem diante das novas políticas mercadológicas. Corpos que só permanecem brincantes no espaço e no tempo porque se autorregulam, se reorganizam, são autopoiéticos em relação ao mundo do qual não fazem parte. Eles são o mundo porque são feitos do mesmo tecido, do mesmo estofo que este é composto.

Seres humanos desafiados por todas as maneiras possíveis: naturais, políticas, econômicas, sociais, se reorganizam e passam à condição de desafiantes. Desafiam o pensamento objetivo e as teses que se constroem sobre corpo

Assim, os brincantes no seu fazer vivem sua experiência estética, trazem em seus corpos saberes, estilos, técnicas, abrem-se ao mundo através do seu sentido estético. Pela percepção e experiência vivida, conhecem, inauguram conhecimento; conhecimento investido na plasticidade e beleza de formas, cores e sons; uma leitura da realidade e da linguagem sensível, possibilitada pela reversibilidade dos sentidos. A plasticidade é desenhada nas constantes reorganização espaços-temporais desse corpo que dança, briga, sofre, entristece, comemora.

Nosso olhar sobre o Bumba meu boi e revela a necessidade de reconhecer a cultura afro-brasileira como portadora de múltiplos sentidos: cultura viva, construída por homens e mulheres que dançam, cantam, simbolizam. Os saberes produzidos nesse cenário se renovam e não podem ser concebidos em sua função de conservação, constituídos por elementos 
petrificados, mas sim, como potencializadores da linguagem sensível, os quais desencadeiam experiências múltiplas que fortalecem a relação entre o ser humano e mundo. E nem podem serem negligenciados como carga inferior em relação ao pensamento hegemônico.

No universo das manifestações afro-brasileiras, no qual situamos a dança, em especial o Bumba-meu-boi do Maranhão, os corpos brincantes produzem e circulam saberes, reelaboram sentidos, sinalizam novas escritas que esperam ser lidas, questionadas; querem continuar aprendendo. Tal investimento implica em novas escrituras, novas interpretações. Sugerimos também uma nova compreensão quanto a esses gestos construídos por um determinado segmento social e que possamos ultrapassar a concepção de petrificá-los no espaço e no tempo.

Os sons produzidos por tambores milenares ainda soam por todo o espaço do mundo, atravessando mares, continentes, embalando danças em diversas culturas, desafiando o tempo, unindo opostos: vida e morte, céu e terra, profano e sagrado; fazendo culturas parecerem idênticas, mesmo ignorando-se; fazendo escritas, gestos adormecidos surgirem em novas significações. Sons produzidos por tambores, tambores construídos e tocados por seres humanos ávidos em completarem-se, concretizarem-se, fazerem-se presentes no cosmo. Seres humanos que enfrentam os desafios do mundo, sempre buscando respostas, procurando significar para além do arcabouço biológico criando símbolos, aguçando sentidos

Enquanto encerramos essas coagulações, séries de visões locais monoculares sobre este papel, as palavras no ar, os tambores continuam tocando, os corpos dançam, continuam escrevendo novas histórias.

\section{REFERÊNCIAS}

ANDRADE, Mário de. Danças dramáticas do Brasil. 2. ed. Belo Horizonte: Itatiaia, 1982. t. 1 .

AZEVEDO NETO, Américo. Bumba meu boi no Maranhão. São Luís: Alcântara, 1983.

BRAGA, Pedro. A ilha afortunada: arquitetura, literatura, antropologia. São Luis: Acervo da Casa de Cultura Josué Montelo, [19--].

CASCUDO, Luís da Câmara. Folclore do Brasil: pesquisas e notas. 2. ed. Natal: Fundação José Augusto, 1980.

CHEVALIER, Jean; GHEERBRANT, Alain. Dicionário de símbolos: sonhos, costumes, gestos, formas, figuras, cores, números. Lisboa: Teorema, 1982. 
CONCEIÇÃO, Jonatas; SIQUEIRA, Maria de Lourdes. África ventre fértil do mundo. Salvador: Associação Cultural Bloco Carnavalesco Ilê-Aiyê, 2001. (Cadernos de educação, 9).

ELÍADE, Mircea. O Sagrado e o profano. 2. ed. São Paulo: Martins Fontes, 2001.

MARQUES, Francisca Ester de Sá. Mídia e experiência estética na cultura popular: o caso do bumba-meu-boi. São Luís: Imprensa Universitária UFMA, 1999.

MORIN, Edgard. O Homem e a morte. 2. ed. São Paulo: Europa-América, 1976.

RAMOS, Arthur. O negro na civilização brasileira. Rio de Janeiro: CEB, 1971. v. 1.

RATTS, Alex; DAMASCENA, Adriane A. Participação africana na formação cultural brasileira. In: BRASIL. Ministério da Educação e Cultura. Educação africanidades Brasil. Brasília: MEC; UNB, 2006.

SANTOS, Luis Carlos dos. A presença negra no Brasil. In: BRASIL. Ministério da Educação e Cultura. Educação africanidades Brasil. Brasília: MEC; UNB, 2006.

VIEIRA FILHO, Domingos. Folclore brasileiro: Maranhão. Rio de Janeiro: Funarte, 1977.

ZUMTHOR, Paul. A letra e a voz: a "literatura" medieval. São Paulo: Companhia das Letras, 1993. 